\title{
Wind profiler observations of a monsoon low-level jet over a tropical Indian station
}

\author{
M. C. R. Kalapureddy ${ }^{1}$, D. N. Rao ${ }^{2}$, A. R. Jain ${ }^{3}$, and Y. Ohno ${ }^{4}$ \\ ${ }^{1}$ Indian Institute of Tropical Meteorology, Pune, India \\ ${ }^{2}$ National Atmospheric Research Laboratory, Gadanki, India \\ ${ }^{3}$ National Physical Laboratory, New Delhi, India \\ ${ }^{4}$ National Institute of Information and Communications Technology (NICT), Tokyo, Japan
}

Received: 20 November 2006 - Revised: 26 May 2007 - Accepted: 3 Ocober 2007 - Published: 6 November 2007

\begin{abstract}
Three-year high-resolution wind observations of the wind profiler have been utilized to characterize the diurnal and seasonal features of the monsoon Low-Level Jet $(\mathrm{LLJ})$ over a tropical station, Gadanki $\left(13.5^{\circ} \mathrm{N}, 79.2^{\circ} \mathrm{E}\right)$, with a focus on the diurnal variability of low-level winds. The Boreal summer monsoon winds show a conspicuously strong westerly LLJ with average wind speed exceeding $20 \mathrm{~m} \mathrm{~s}^{-1}$. The L-band wind profiler measurements have shown an advantage of better height and time resolutions over the conventional radiosonde method for diurnal wind measurements. An interesting diurnal oscillation of LLJ core has been observed. It is varying in the height range of $1.8 \pm 0.6 \mathrm{~km}$ with the maximum and minimum intensity noticed during the early morning and afternoon hours, respectively. The jet core (wind maxima) height is observed to coincide with the inversion height. Strong wind shears are normally located beneath the LLJ core. The sole wind profiler observations are capable of identifying the monsoon phases, such as onset, break and active spells, etc. The mutual influence between the LLJ and the boundary layer has been discussed. One notices that the observed LLJ diurnal structures depend on the local convective activity, wind shears and turbulence activity associated with boundary layer winds. The day-to-day change in the LLJ structure depends on the latitudinal position of the LLJ core.
\end{abstract}

Keywords. Meteorology and atmospheric dynamics (Synoptic-scale meteorology; Tropical meteorology; Turbulence)

\section{Introduction}

Wind plays a vital role in atmospheric energetics. It transports heat, mass, moisture and pollutants from one place to

Correspondence to: M. C. R. Kalapureddy

(kalapureddy1@gmail.com) another. These transport processes, in turn, affect the local weather, as well as climate. Hence, the characterization of wind and its variability is extremely important. So, detailed observations of winds are necessary with high spatial and temporal resolutions.

An important atmospheric phenomenon that occurs over the Indian sub-continent is the monsoon. It accounts for the majority of the annual total rainfall. The monsoon is strongly coupled with the warm oceans surrounding the subcontinent. There are monsoon-related phenomena whose associations are very much prominent in deciding the vigor of the monsoon. Two such phenomena are the Low-Level Jet (LLJ) and Tropical Easterly Jet (TEJ). These two synoptic-scale jets are associated with the boreal summer (southwest) monsoon and located at $850 \mathrm{hPa}$ and $150 \mathrm{hPa}$, respectively, over southern India (Joseph and Raman, 1966; Findlater, 1966, 1967; Mokashi, 1974; Desai et al., 1976). The wind speeds associated with the LLJ are less than $30 \mathrm{~m} \mathrm{~s}^{-1}$, but occasionally they exceed this value. The WMO definition of the jet (wind speeds exceeds $30 \mathrm{~m} \mathrm{~s}^{-1}$ ), basically meant for the TEJ, may not be often valid for the LLJ. In spite of this fact, a lowlevel $(850 \mathrm{hPa})$ wind system having a strong wind and wind shear has been named as an LLJ. This jet stream is often observed during June-August and is strongest in July, in the southern part of India (Joseph and Raman, 1966). In general, LLJ has a wind speed maximum that occurs in the lowest few kilometers of the atmosphere, and wind speeds should show a decrease on either side of the wind maximum. Usually, a Low-Level Atmospheric Jet is supposed to be a nocturnal phenomenon (Stull, 1990) and is one of the interesting features of the stable boundary layer that is well documented at diverse locations (for a review, see Wipperman, 1973; Stensrud, 1996). The LLJ observed over the Indian peninsula is an Afro-Asian cross-equatorial phenomenon. Joseph and Raman (1966) first examined the LLJ features over the peninsular India followed by Desai et al. (1976), which confirms the existence of a westerly LLJ stream with strong vertical and

Published by Copernicus Publications on behalf of the European Geosciences Union. 
horizontal wind shears. The LLJ over tropical India could have a strong link with the Indian monsoon rainfall (Findlater, 1969). Later, wind analysis by Findlater (1971) has shown that there is a cross-equatorial strong wind flow from South Africa to Indian Ocean and southern India via Somalia. Many researchers studied various aspects of this synoptic cross-equatorial jet (e.g. Krishnamurti et al., 1976, 1983; Hart et al., 1978; Newton, 1981). But almost all the earlier observations were normally based on radiosonde/rawinsonde observations taken twice a day. However, those observations, poor in resolution, were not sufficient to explore some of the important features of the LLJ, such as diurnal variation and its influence on the local boundary layer through turbulence and vertical velocities. The high-resolution observations are required to explore these important features.

Advancement of the remote sensing Doppler radar wind profiling technology allows us to make a continuous highresolution (both height and time) vertical profile of wind measurements in the first few kilometers of the lower troposphere through clear sky much easier and automatically in a cost-effective way. In addition to their ability to measure atmospheric winds, the profilers have a unique capability of measuring vertical wind directly. However, wind profilers could miss some of the LLJs, which occur at heights below $500 \mathrm{~m}$ (Stensrud et al., 1990). In spite of the difficulties involved in the remote wind sensing, a continuous, long-term record of lower level wind profiles is the best means to explore the fine features, such as the diurnal variation of the LLJ.

The objective of this paper is to explore the monsoon induced LLJ characteristics and their influence on the boundary layer features. By taking advantage of the high-resolution observations of LAWP, special attention is given to explore the diurnal variation of the LLJ. Further, three-year wind measurements are examined for seasonal and day-to-day variation of the low-level wind over Gadanki.

\section{Site, system and data description}

The experimental site, National Atmospheric Research Laboratory (NARL), is located at Gadanki $\left(13.5^{\circ} \mathrm{N}, 79.2^{\circ} \mathrm{E}\right)$, situated in the southern part of the tropical India, $\sim 370 \mathrm{~m}$ above the mean sea level, and is shown in Fig. 1. This site is situated in a rural environment surrounded by hillock, whose heights are around $200-700 \mathrm{~m}$, within a $10-\mathrm{km}$ radius and is a mixture of agricultural and population centers and is about $120 \mathrm{~km}$ to the northwest of Chennai, which is on the east coast of the Indian peninsula. A three-dimensional view of the main topography around Gadanki is shown in Fig. 1c. However, the topography of the site is not exclusively considered for the present study.

India Meteorological Department (IMD) has defined the meteorological conditions over the Indian sub-continent. The seasons over India are divided into winter (January and
February), pre-monsoon/summer (March, April, and May), monsoon/South-West (SW) monsoon (June, July, August, and September), and post-monsoon/North-East (NE) monsoon (October, November, and December). SW and NE monsoons are also known as the summer-monsoon and winter-monsoon, respectively. These two monsoons account for the majority of the annual total rainfall. The two monsoons are different in the sense that in summer, warm equatorial maritime air predominates over a major portion of the country. In winter, the air masses recede south and are replaced by the cool tropical continental air. The normal onset of the SW monsoon is around the first week of June and withdrawal occurs during the middle of September. After onset of the SW monsoon, it takes around a week to observe it at the observational site. The normal day mean surface temperatures during the cardinal months of January, April, July, and October are around 23, 30, 30, and 28 degree Celsius, respectively, at almost all of the IMD sites in the southern part of India. The mean wind is southwesterly during the monsoon season and for the rest of the seasons, northeasterly. Sky conditions defined in this study are clear-air, which means that the atmosphere is predominantly free from precipitating clouds and vertical velocities are of the order of a few centimeters per second.

In India, the first L-band Doppler radar, known as Lower Atmospheric Wind Profiler (LAWP), is operational at NARL. The LAWP at Gadanki is the first boundary layer wind profiler dedicated to the detailed investigation of the Atmospheric Boundary Layer (ABL) characterization via winds, turbulence and precipitating systems in the tropical latitudes (Krishna Reddy et al., 2002; Krishna Reddy, 2003a, b, c, d; Krishnan and Kunhikrishnan, 2004; Krishnan et al., 2005; Kalapureddy et al., 2007). Gadanki is an ideal site to serve as ground validation of the Tropical Rainfall Measuring Mission (TRMM) satellite because of its location and availability of multiple sensors at NARL. The LAWP operates in the Lband region at $1357.5 \mathrm{MHz}$ with a peak power aperture product of $1.2 \times 10^{4} \mathrm{~W} \mathrm{~m}^{2}$. It provides the valuable wind information in three different directions, corresponding to Zenith and off-zenith $\left(15^{\circ}\right)$ towards North and East. The LAWP is operated continuously with height and time resolutions of $150 \mathrm{~m}$ and $\sim 10 \mathrm{~min}$, respectively, and the data is recorded in a power spectral form. Detailed LAWP system and experimental specifications, as well as data and relative availability of wind measurements can be found in Krishna Reddy et al. (2001, 2002). The parameterization of the Doppler signal spectrum data of LAWP, in the present study, follows closely the procedure adopted at the Poker Flat radar (Riddle, 1983). The three lower order spectral moments, the signal strength, the weighted mean Doppler shift, and the spectral width are computed then through numerical integration using the expressions given by Woodman (1985). The mean Doppler shift provides a direct measure of the radial velocity of scattering refractive irregularities which act as tracers of the background wind. The measurements taken with three 
(a)

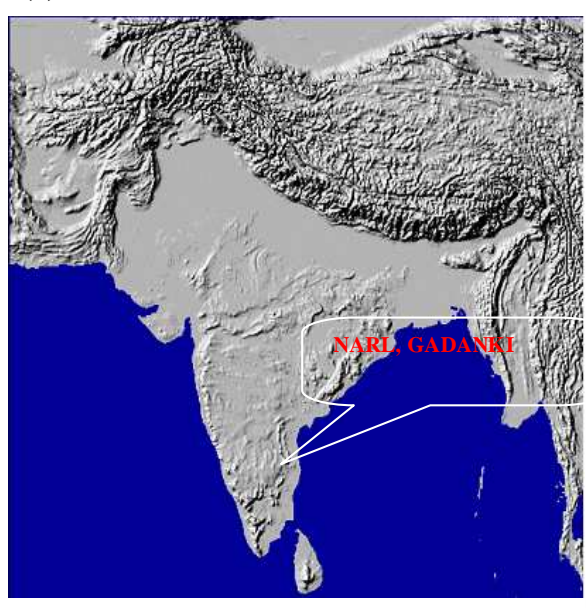

(b)

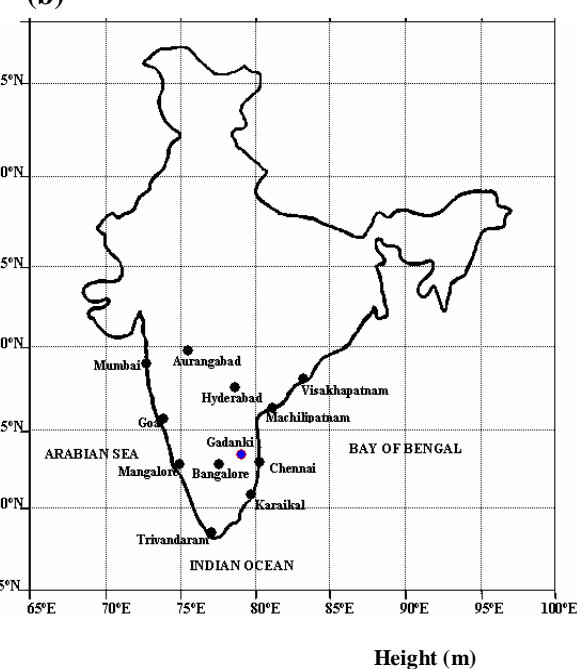

(c)

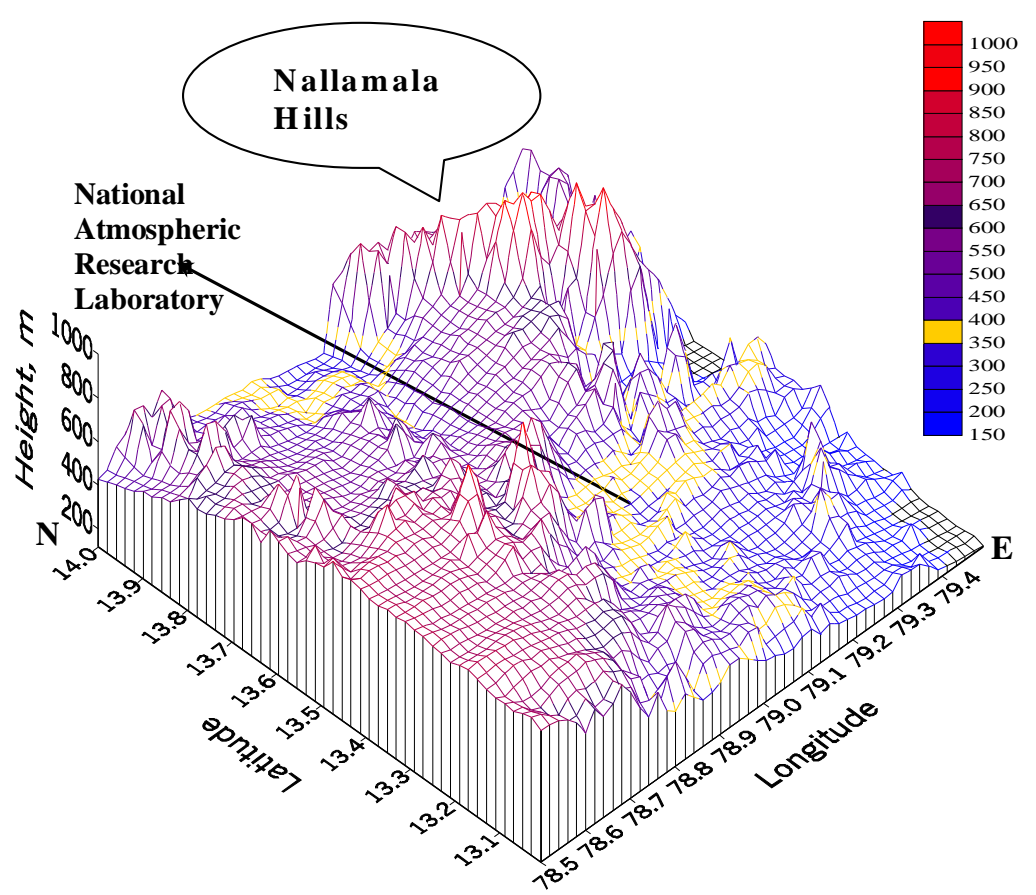

Fig. 1. (a) Geographical location of NARL, Gadanki (b) Location of Gadanki and southern IMD stations (c) Three-dimensional view of the main topography around Gadanki (after Krishna Reddy et al., 2002).

non-coplanar beam positions are utilized to obtain the threewind vectors, viz., Zonal (U), Meridional (V), and Vertical (W). Further details on the analysis procedure can be found in Anandan et al. (2005). The LAWP wind measurements, during 1998-2000, have been used to study the monsoon LLJ characteristics. More focus has been given on the monsoon period wind observations. The major data gaps during April 1998 were due to an FTP failure to record online data and from August 1998-March 1999 were due to major damage of the outdoor transmitter unit. The minor data gaps were pertained mainly from the system failure, due to a power supply/UPS failure during severe weather hazards and system maintenance. The observations that are presented correspond to the height range of $0.45-5.1 \mathrm{~km}$. During the clear air days, the maximum height coverage (detectability) ranges from 2.7 to $6.0 \mathrm{~km}$ and it mainly depends on the background meteorological conditions. Generally, during the premonsoon and the monsoon seasons, the maximum height coverage is up to $6.0 \mathrm{~km}$ and during the post-monsoon and winter seasons it is below $2.7 \mathrm{~km}$. The height coverage increases even above $9.0 \mathrm{~km}$ during the precipitation. During the monsoon, convection and monsoon rains dominate over 
5-days Mean Horizontal Wind (Gadanki)
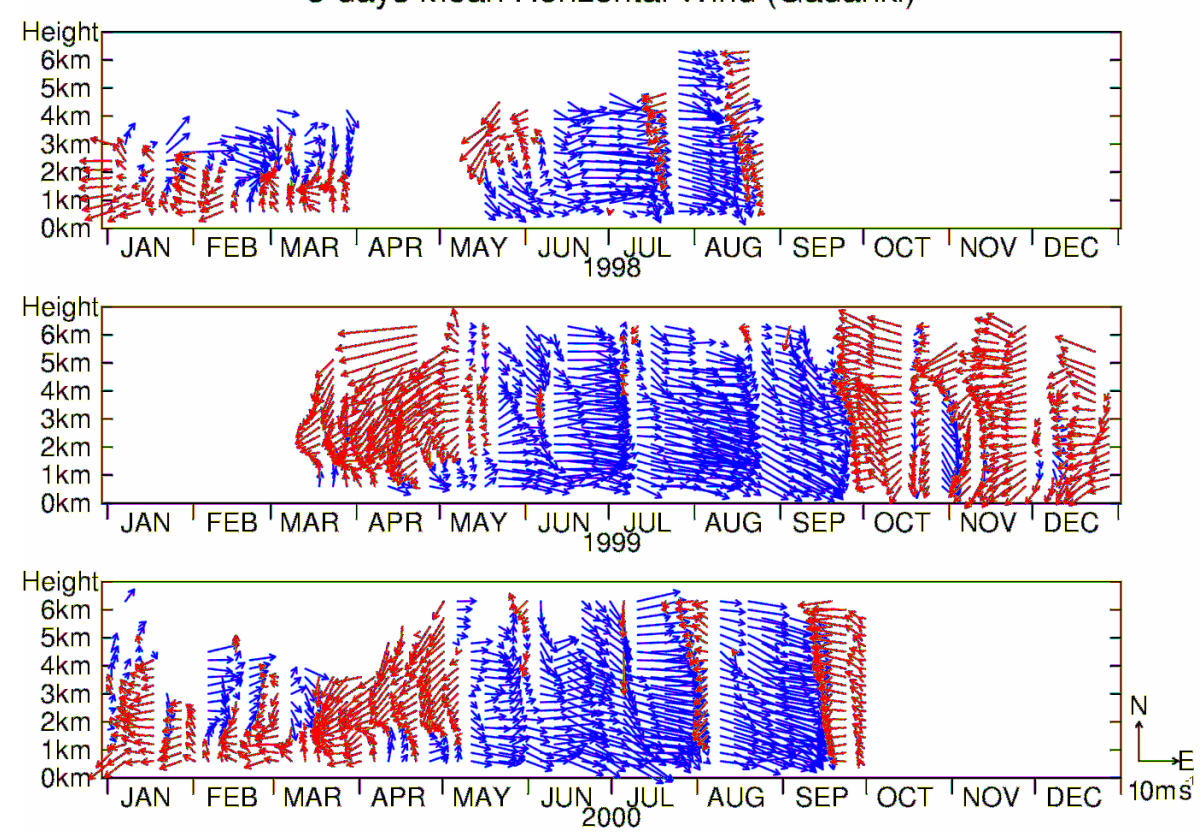

Fig. 2. Five-day mean horizontal winds observed for (top) 1998, (middle) 1999, and (bottom) 2000.

southern India. Hence, it is necessary to separate out the data that corresponds to the clear-air and the precipitation conditions. This is important since LAWP, which operates at $1.3 \mathrm{GHz}$, is highly sensitive to hydrometeors. So, it is obvious that the precipitation echoes mask the clear-air echoes and thus it is very difficult to estimate the background wind. Hence, in this study only the clear-air data of LAWP are considered. The observed wind vectors using the LAWP have been compared with the co-located Indian MST radar and found to be in good agreement with correlation coefficients of $0.94,0.80$, and 0.78 , respectively, for zonal, meridional and vertical wind vectors (Madhu C Reddy et al., 2000; Krishna Reddy et al., 2002).

LAWP observed echo power and spectral width are utilized, respectively, for estimating the atmospheric turbulence refractivity structure parameter $\left(C_{n}^{2}\right)$ and the eddy dissipation rate $(\varepsilon)$, to characterize the local boundary layer. $C_{n}^{2}$ is the structure parameter that characterizes the strength of the refractive index fluctuations and $\varepsilon$ deals with the turbulence intensities in the velocity field. $\varepsilon$ is one of the fundamental parameters used to determine the turbulence characteristics. The sharp increase in $C_{n}^{2}$ is confined to the top of the boundary layer where a sudden change in atmospheric refractivity is due to changes in atmospheric temperature and humidity. The sharp decrease in $\varepsilon$ above the boundary layer indicates the diminishing of turbulent eddies of sizes comparable to half of radar wavelength above the boundary layer. So, the sharp gradient feature of these parameters observed around the boundary layer top can be used to estimate the boundary layer depth (Angevine et al., 1994; White, 1993; San- dra Jacoby-Koaly et al., 2002). Hence, this gradient feature, from here on, is utilized to find the boundary-layer depth/top from sole radar measurements. The detailed estimation of $C_{n}^{2}$ and $\varepsilon$ used in this study can be found in Kalapureddy et al. (2007).

\section{Results and discussion}

\subsection{General LLJ characteristic features over Gadanki}

Figure 2 shows the seasonal features of the low-level winds, averaged for 5 days, for all the months during 1998, 1999 and 2000. In this figure, the arrow head indicates the wind direction and the length of the arrow represents the magnitude of the wind speed. It is evident from the figure that the wind structure has a consistent common characteristic feature corresponding to each of the seasons over Gadanki. The strong westerly (blue arrows) winds prevail during the monsoon season over the peninsular India. Easterlies are predominant (red arrows) during the rest of the seasons. Setting of the well-organized westerlies can be seen from the first week of June onwards, which is the monsoon onset period over India (Krishnamurti, 1985; Joseph et al., 1994). During July and August, strong westerly winds are commonly observed. The intervening brief easterlies during the monsoon season are observed to be associated with the break phase of the monsoon. A gradual seasonal change in the wind direction from easterly to westerly is noticed around the monsoon onset period, during the middle of May, and the westerly to 
Table 1. Summary of LAWP observed low-level jet features over Gadanki during 1998-2000.

\begin{tabular}{|c|c|c|c|c|c|c|}
\hline $\begin{array}{l}\text { Sl. } \\
\text { No. }\end{array}$ & Season & $\begin{array}{l}\text { LLJ's nature \& average } \\
\text { frequency per month }\end{array}$ & Wind direction & $\begin{array}{l}\text { Wind speed } \\
\left(\mathrm{m} \mathrm{s}^{-1}\right)\end{array}$ & $\begin{array}{l}\text { LLJ vertical ex- } \\
\text { tension }(\mathrm{km})\end{array}$ & Remarks \\
\hline 1 & $\begin{array}{l}\text { Pre-monsoon (summer) } \\
\text { March-May }\end{array}$ & $\begin{array}{l}\text { *Nocturnal \& } 15 \text { days } \\
\text { per month }\end{array}$ & $\begin{array}{l}\text { Easterly/ } \\
\text { Westerly }\end{array}$ & $12-18$ & $1.2-3.6$ & $\begin{array}{l}\text { Meridional wind is domi- } \\
\text { nant. Weak south-easterly } \\
\text { and strong northeasterly are } \\
\text { merging at } \sim 1.8-2.1 \mathrm{~km} \text {. }\end{array}$ \\
\hline 2 & $\begin{array}{l}\text { Monsoon } \\
\text { June-September }\end{array}$ & $\begin{array}{l}{ }^{* *} \text { Day long \& } 20 \text { days } \\
\text { per month }\end{array}$ & Westerly & $14-24$ & $0.6-4.5$ & $\begin{array}{l}\text { Zonal wind is dominant. } \\
\text { Strong westerlies observed } \\
\text { for many days are indicat- } \\
\text { ing an active phase of mon- } \\
\text { soon. Meager winds with } \\
\text { wind reversal are observed } \\
\text { to be associated with break } \\
\text { monsoon periods. }\end{array}$ \\
\hline 3 & $\begin{array}{l}\text { Post-monsoon } \\
{ }^{\#} \text { October-December }\end{array}$ & Nocturnal & Easterly & $7-9$ & $0.6-1.8$ & $\begin{array}{l}\text { Winds are mostly weak and } \\
\text { northerly/easterly. }\end{array}$ \\
\hline 4 & $\begin{array}{l}\text { Winter } \\
\text { January-February }\end{array}$ & $\begin{array}{l}\text { Nocturnal \& } 10 \text { days per } \\
\text { month }\end{array}$ & Easterly & $12-14$ & $0.6-2.1$ & $\begin{array}{l}\text { Meridional wind is domi- } \\
\text { nant below } 1.5 \mathrm{~km} \text {. Weak } \\
\text { easterly and strong westerly } \\
\text { are observing below and } \\
\text { above } 2 \mathrm{~km} \text {, respectively. }\end{array}$ \\
\hline
\end{tabular}

Data used: 18 February 1998-24 August 1998 (116 days); 17 March 1999-30 December 1999 (282 days); 3 January 2000-29 September 2000 (263 days)

Data gap dates: March 1998 (7, 8, 15, 16, 18); May 1998 (16, 30, 31); June 1998 (5, 7-9, 27-28); July 1998 (5, 25, 26); August 1998 (2, 12-15); March 1999 (29); October 1999 (10-13, 31); January 2000 (30, 31); February 2000 (26); April (17); June 2000 (6, 17, 18); August $2000(14,22)$ along with bulk data gap during 28 March 1998-15 May 1998

* Confined around 22:00-09:00 LT; ${ }^{* *}$ Confined to whole time of the day; ${ }^{*}$ information based only on 1999 data.

easterly change is observed around the middle of September, which is the monsoon withdrawal period.

The general LLJ features associated with each season and the remarkable characteristics are summarized for the wind observations during 1998-2000 and presented along with the database in Table 1. Generally, the LLJ characteristic features during the winter and pre-monsoon are observed to be easterly in direction, and wind magnitudes are of the order of 14 to $16 \mathrm{~m} \mathrm{~s}^{-1}$ with a varying height in the jet core of $1.6 \pm 0.3 \mathrm{~km}$. The LLJ features noticed with our limited data set, corresponding to the post-monsoon period, reveals that the LLJ is weak and seldom. The LLJ features observed during the monsoon, which is the focus of this paper, are relatively stronger and frequent, whereas during other seasons LLJ is nocturnal in nature with low intensity and only on occasional occurrence. The LLJ during the monsoon period is westerly in direction and the wind magnitude is 15 to $25 \mathrm{~m} \mathrm{~s}^{-1}$ with jet core heights varying $1.8 \pm 0.6 \mathrm{~km}$. The largest vertical thickness (spread) of the LLJ during the monsoon is observed to be $\sim 3.9 \mathrm{~km}$. It has been observed that LLJ features appear to be conspicuously stronger in their magnitudes and daylong existence for a few continuous days during the active phase of the monsoon. The wind profiler which made high-resolution vertical wind profiles allowed us to obtain the LLJ evolution and depth information which is believed to be better than the previous radiosonde-based observations. However, the other important features of the LLJ, such as length and width information, demands a network of observations covering a larger area. For such observations, the radiosonde network still shows the promise.

\subsubsection{LLJ characteristics during the active monsoon period (July-August)}

The horizontal and the vertical structures of the LLJ during the monsoon period have been explored using the contemporaneous National Center for Environmental Prediction (NCEP)/National Center for Atmospheric Research (NCAR) reanalysis wind data and the southern IMD radiosonde/rawinsonde data along with the LAWP observed winds. The period of 15 July-15 August 1999 (32 days) is chosen for exploring the day-to-day LLJ characteristics pertaining to the active and the break monsoon phases. This period has been selected due to the availability of both the radiosonde measured vertical profiles of meteorological parameters and the fairly continuous LAWP winds at the observational site. The LAWP observed zonal winds are used to look at the height-time structure of the LLJ over the observational site and is shown in Fig. 3 (top). Data gaps are left as white patches. This figure clearly demonstrates the fine day-to-day changes along with remarkable diurnal 


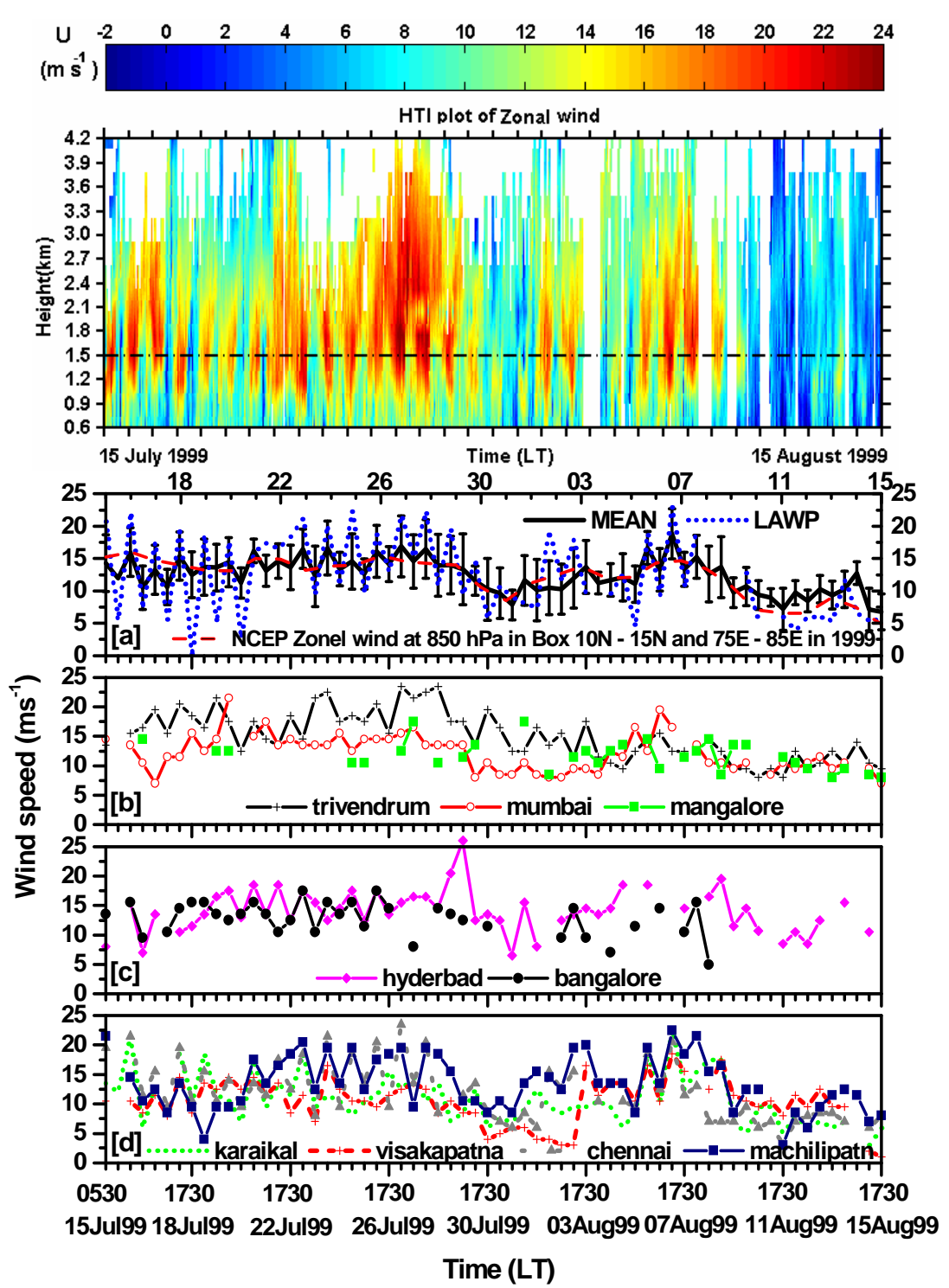

Fig. 3. (Top) Height-Time Intensity (HTI) map of zonal wind observed during 15 July-15 August 1999. (a) $850 \mathrm{hPa}$ level mean wind observed with the southern India IMD stations (solid line) the vertical bars are standard deviations, corresponding to the LAWP zonal wind at $1.5 \mathrm{~km}$ (dotted line) and NCEP $850 \mathrm{hPa}$ mean zonal wind in grid $10^{\circ}-15^{\circ} \mathrm{N}$ and $75^{\circ}-80^{\circ} \mathrm{E}$ (dashed line). The wind speed observations of IMD stations over (b) west coast, (c) land stations in between the two coasts over India, and (d) east coast.

variation of the LLJ. The strong westerly winds with varying intensities and a clear oscillation of a level of maximum wind (LLJ core) have been noticed over the course of the days during 25-28 July 1999. These features pertain to the active monsoon phase. During the active phase, the jet stream extends from the height region of $0.9-4.2 \mathrm{~km}$, where the jet core is oscillating in the range $1.8-2.4 \mathrm{~km}$ with wind speeds exceeding $20 \mathrm{~m} \mathrm{~s}^{-1}$ at the jet core. The weak zonal wind magnitude along with a change in sign (westerly to easterly), almost persisting for the few continuous days during 11-15 August 1999, is an indication of break monsoon phase. Hence, LAWP is capable of identifying the ac- tive and the break phase of monsoon by its solo wind information. The wind speed at $850 \mathrm{hPa}$, during 05:30 and 17:30 LT (LT=UTC+05:30), and the radiosonde observations from 15 July-15 August 1999 are averaged, respectively, for the southern IMD stations (see Fig. 1 for location of the stations); the mean and standard deviation are shown in Fig. 3a. The LAWP observed zonal winds (dotted line) at $1.5 \mathrm{~km}$ around the radiosonde observation period show a good comparison with the NCEP reanalysis and the southern India IMD stations' mean wind at $850 \mathrm{hPa}$. The pronounced variation in the LAWP observed LLJ can be attributed to the strength of its high-resolution observations, in addition to the 

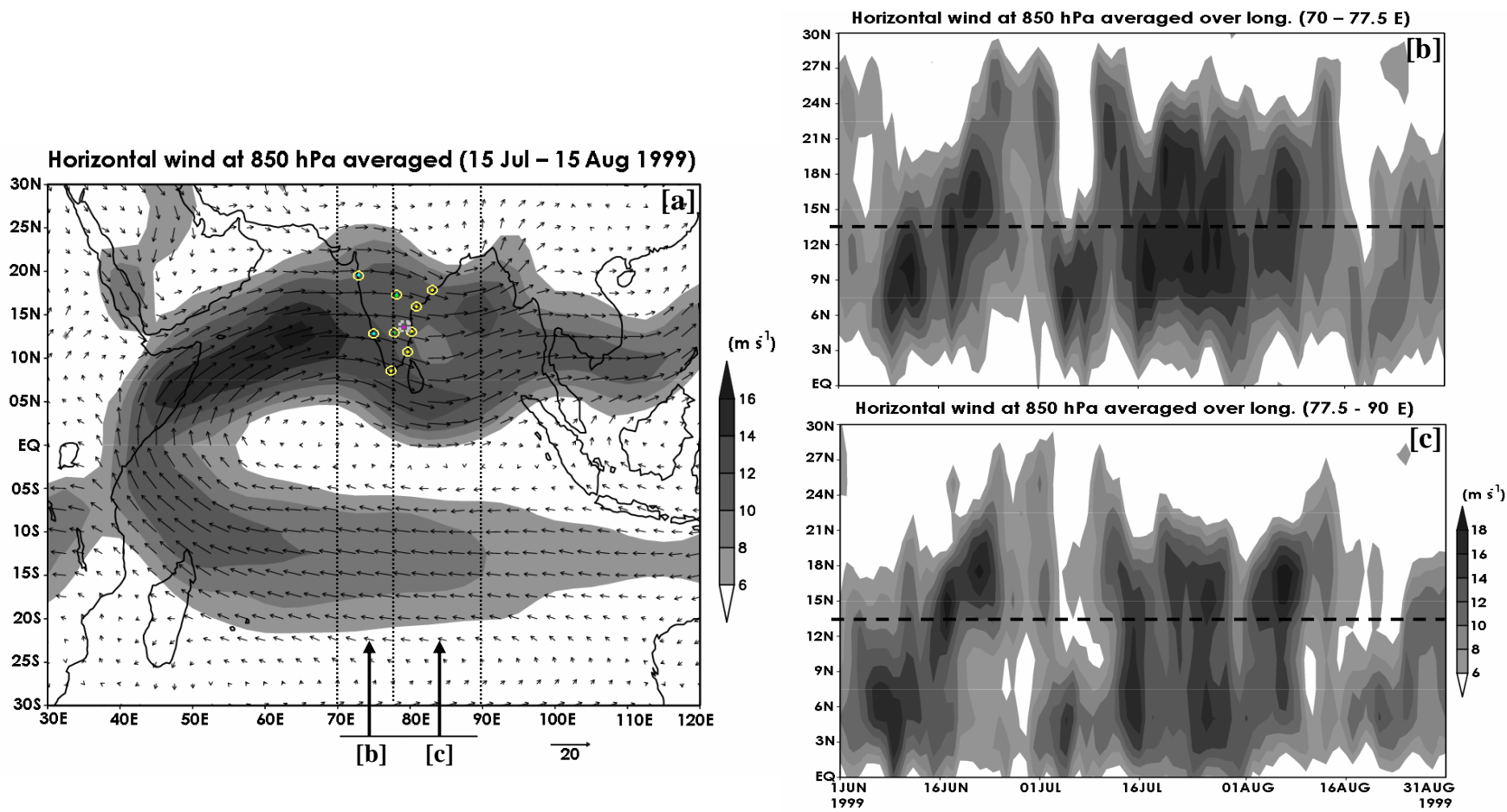

Fig. 4. (a) NCEP/NCAR reanalysis 850 -hPa level wind averaged for the period 15 July-15 August 1999 . The $850 \mathrm{hPa}$ level wind during 1 June-31 August 1999 is averaged for longitudinal band (b) $70-77.5^{\circ} \mathrm{E}$ and (c) $77.5-90^{\circ} \mathrm{E}$.

local variability of wind. The observations in the IMD stations are classified into the west coast, land stations in between the two coasts over India, and east coast, to access the gradients in the horizontal winds, and are shown, respectively, in Figs. 3b, c and d. These panels clearly show the gradients in the horizontal winds over southern India. These gradients in winds may partly pertain to the complexity of the monsoon winds and partly be due to the monsoon flow modification by the local boundary layer and topography.

The global mean wind picture during 15 July-15 August 1999 can be understood from NCEP/NCAR reanalysis data (Kalnay et al., 1996) at $850 \mathrm{hPa}$ level with $2.5^{\circ} \times 2.5^{\circ}$ grid resolutions confined to 00:00 UTC on each day. The mean wind speed with its direction contour over $30^{\circ} \mathrm{N}-30^{\circ} \mathrm{S}$ and $30^{\circ} \mathrm{E}-120^{\circ} \mathrm{E}$ are shown in Fig. 4a. This figure confirms the existence of a strong synoptic monsoon-induced wind flow over the southern part of India. This figure also shows that the LLJ extended over the Indian latitude region $2^{\circ} \mathrm{N}-22^{\circ} \mathrm{N}$ and the LLJ core is confined over the latitude region $8^{\circ} \mathrm{N}-$ $15^{\circ} \mathrm{N}$, right over Gadanki. The width and wind speeds associated with the LLJ core are noticed to be relatively more at the west coast than at the east coast of India. Further, in order to find the exact latitudinal position of the oscillating LLJ core, the evolution of the LLJ core at the west coast $\left(70.0^{\circ} \mathrm{E}-\right.$ $\left.77.5^{\circ} \mathrm{E}\right)$ and the east coast $\left(77.5^{\circ} \mathrm{E}-90.0^{\circ} \mathrm{E}\right)$ of India has been shown in Figs. $4 \mathrm{~b}$ and c, using the NCEP mean wind at $850 \mathrm{hPa}$ during 1 June-31 August 1999. There is a significant latitudinal difference in the LLJ core evolution and structure between the west coast and east coast of India. This could be mainly due to the ocean-to-land frictional contrast. It can be noticed from Fig. $4 \mathrm{c}$ that during the LAWP observed active monsoon phase, 25-28 July 1999, the LLJ core is located around the observation site. Hence, from Fig. 3 (top) and Fig. $4 \mathrm{c}$, it can be understood that the height-time structures of the LLJ revealed by LAWP shows a good correlation with the latitudinal position of the LLJ core. Hence, the observed LLJ structures are due to the latitudinal oscillation of the LLJ core. It is worth pointing out that the probable location of the LLJ core is sensitive to the location of the convective heating area, which plays a key role in deciding the phase of the monsoon around India (Joseph and Sijikumar, 2004). They also mentioned that during the active phase of the monsoon the east-west band of strong convective heating, confined in the latitude region $10^{\circ} \mathrm{N}-20^{\circ} \mathrm{N}$, causes the LLJ axis to pass through the peninsular India. So, it can be understood from Figs. 3 and 4 that the LAWP observed height-time structures of the LLJ are the clear signature of the large-scale, complex, monsoon flow passing over Gadanki.

\subsubsection{Diurnal evolution of the monsoon LLJ and its effects on the boundary layer}

The simultaneous LAWP and radiosonde observations carried out at Gadanki have been utilized to understand the diurnal variability of LLJ. The height profiles of various ABL 


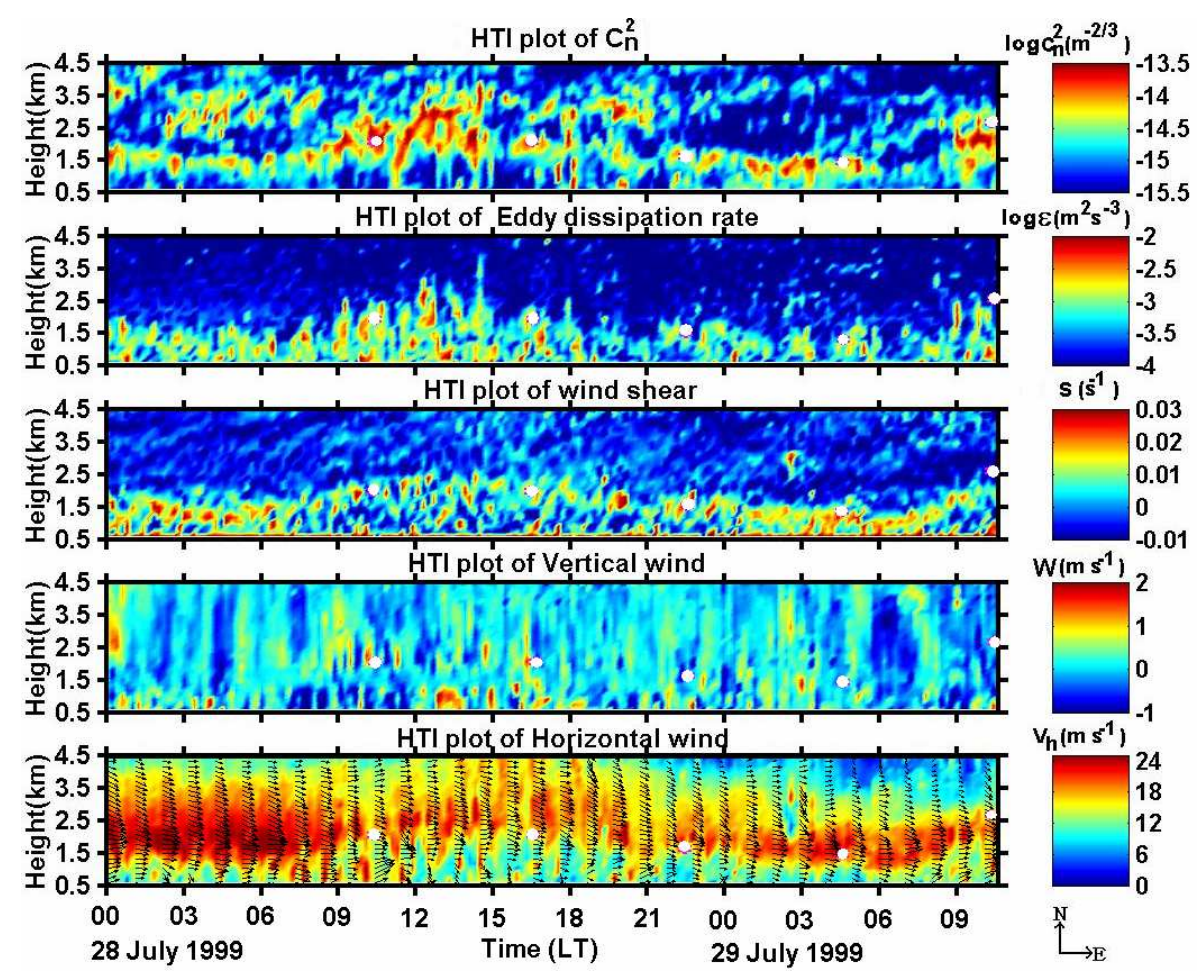

Fig. 5a. (Top to bottom) HTI panels show radio refractive index structure parameter $\left(C_{n}^{2}\right)$, eddy dissipation rate $(\varepsilon)$, wind shear $(\mathrm{S})$, vertical wind $(\mathrm{W})$, horizontal wind speed $\left(V_{h}\right)$ with four hourly averaged wind direction, and observed during 28-29 July 1999 . The white circles correspond to the boundary layer top estimated from radiosonde observations.

dynamical and meteorological parameters, derived from simultaneous LAWP and radiosonde observations, on 28-29 July 1999, are shown in Figs. 5a and b. These two days, i.e. 28-29 July 1999, represent the typical active monsoon LLJ days. Figure 5a shows HTI maps of the turbulence related parameters $\left(C_{n}^{2}\right.$ and $\varepsilon$ ), and dynamical parameters (horizontal wind speed $\left(V_{h}\right)$ with hourly wind direction, vertical shear of the horizontal wind (S), and W), during 28-29 July 1999. In Fig. 5b, each horizontal panel corresponds to a particular time of the radiosonde launch during 10:30 LT on 28 July 1999 to 10:30 LT on 29 July 1999, with an observational interval of every six hours. The height profiles of $\mathrm{W}, C_{n}^{2}$, $\varepsilon, V_{h}$, and $\mathrm{S}$ are computed using the LAWP measurements averaged over $20 \mathrm{~min}$ around the radiosonde launch time. The radiosonde measured parameters are used to compute the potential temperature $(\theta)$ and the Richardson Number $\left(\mathrm{Ri}=\frac{g}{\theta} \frac{d \theta}{d z} / S^{2}\right)$. It can be seen from Fig. 5a that the horizontal wind speed shows strong westerly oriented LLJ features with diurnal variability in intensity and height of the LLJ core. The LLJ structure during 09:00-22:00 LT, with its core height elevated as high as $3.0 \mathrm{~km}$, is not very coherent. The LLJ structure is very much organized and relatively stronger during 22:00-09:00 LT with an LLJ core at its lower height at $1.8 \mathrm{~km}$. It can be noticed that the sharp gradient in height profile of $\theta$ (gray line in 1st column panel of Fig. 5b), indicating the top of the boundary-layer (Angevine et al., 1994), shows a good correlation with the LLJ core height. The significant change in wind speed with a clear oscillation in the level of maximum wind during the course of the day can be seen in the right-most column panels of Fig. 5b. A near similar feature has been reported by Ardanuy (1979). It is also observed that the LLJ core height is confined to the level of boundary layer inversion. Similar features are reported by Yihua Wu and Sethu Raman (1998). It can be noticed from Fig. 5a that the positive shears are more dominant during nocturnal hours, at the lower flange of the LLJ. It is interesting to note that there exists a consistent secondary wind maximum just below the LLJ at $\sim 1 \mathrm{~km}$ before noon, i.e. $\sim 10: 30 \mathrm{LT}$ (see Fig. 5b). The exact reasons for the existence of such a phenomenon have yet to be understood. But it is likely that the interaction of the existing early morning strong LLJ with the local tidal wave activity exhibited by the pressure pattern might have caused the wind gradients, which may be one of the reasons for the double maxima in the wind profile at around 10:30 LT. The other probable reason might be the interaction between the existing strong low-level winds with a gradual rise in the convectively forced boundary layer inversion, after 09:00 LT (see Fig. 5a). The convective force associated with the CBL pushes the inversion layer, consequently lifting the LLJ core. The strong winds below the inversion still persist but with less vigor compared to prime LLJ. This 


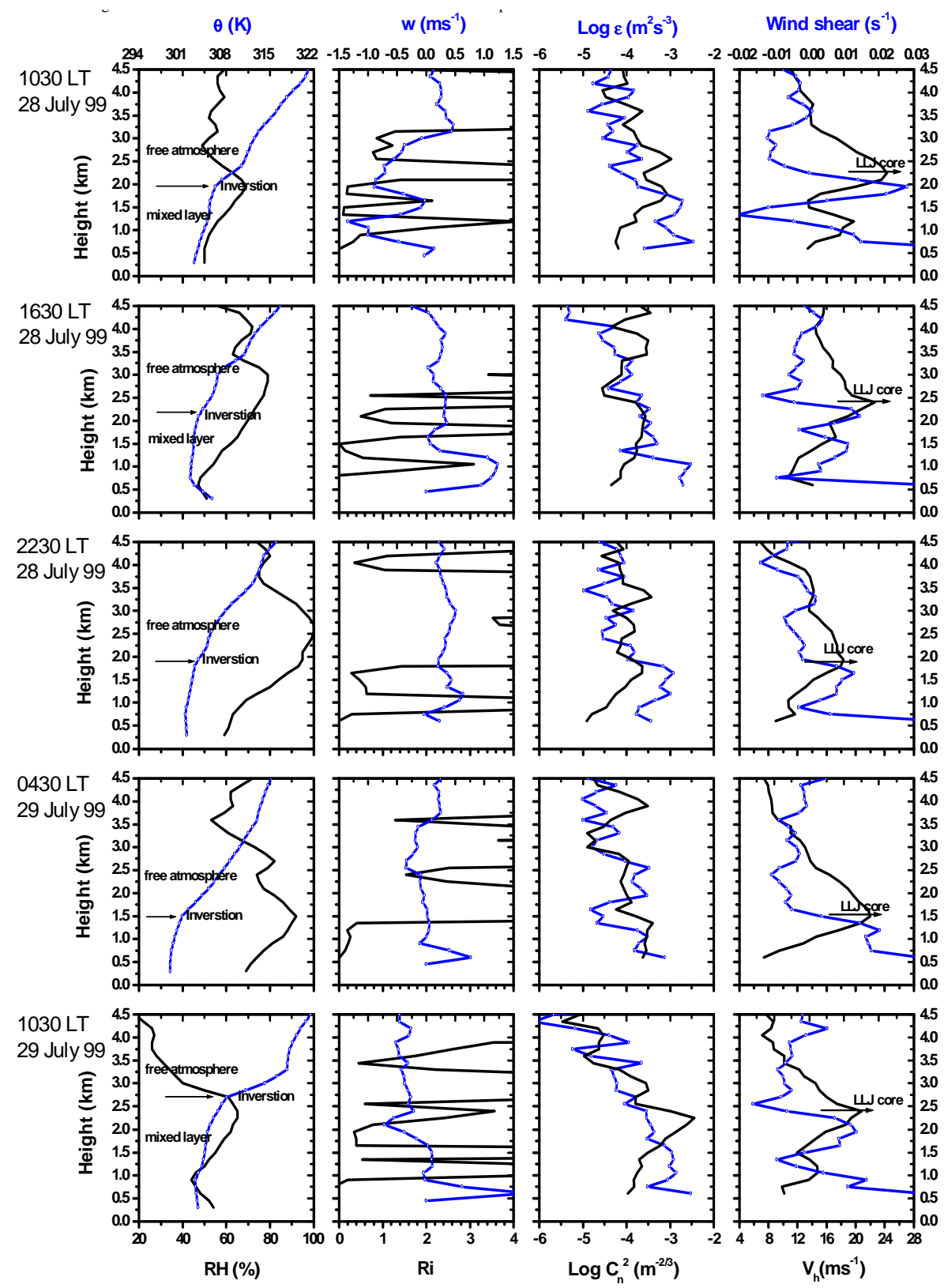

Fig. 5b. Height profiles of various parameters for every $6 \mathrm{~h}$ interval from 10:30 LT on 28 July 1999 to 10:30 LT on 29 July 1999 can be seen from top to bottom row panels, respectively. Arrows indicate the height of the inversion layer and the LLJ core.

secondary peak in the wind profile below the core of the LLJ has been observed to cease before noon. The presence of vigorous convective mixing associated with the CBL during the midday might have made the boundary layer winds more homogeneous, causing the secondary wind maximum to be eroded. The observed strong vertical velocities of the order of more than $1 \mathrm{~m} \mathrm{~s}^{-1}$ during 12:00-18:00 LT confirmed the presence of strong convective activity (see Fig. 5a). The convective forces associated with CBL might have also been responsible for the rugged nature of the LLJ during the CBL period. Hence, due to the combined effect of the elevated in- version layer around $1.5 \mathrm{~km}$, tidal wave activity and relatively less convective activity (meager vertical velocities) during the before noon hours (i.e. 10:30 LT) might have been conducive to the existence of a secondary maxima in wind profile. Similar observations were reported by Findlater (1977) but he noticed it during late afternoon. It can be noticed that the LLJ core height varies with time, and strong wind shears are noticed on either side of the jet core. These LLJ induced shears in the boundary layer can have an impact on the local turbulence parameters. It is observed that the vertical structure of the LLJ depends on the wind shear, turbulence, 


\section{Monthly mean diurnal features of Horizontal winds} 1999
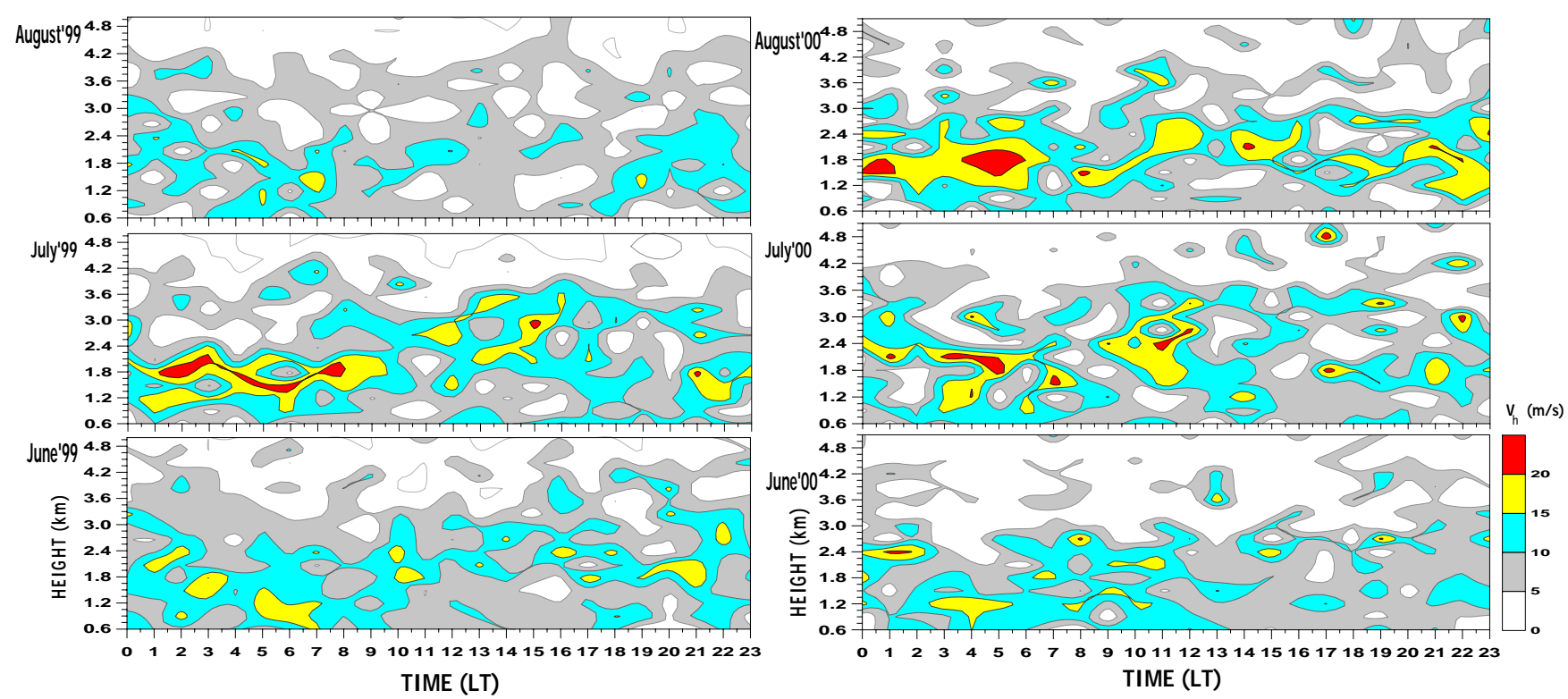

Fig. 6a. (Left and right) Mean monthly diurnal features of horizontal wind contours for June (bottom), July (middle) and August (top) for 1999 and 2000.

and vertical wind information. Such altitudes, where the Ri value is less than one, represent the regions where turbulent layers are likely to be present (Atlas et al., 1968). Around the inversion height (boundary layer top) the Ri is below the critical value. The frequency of the turbulent layers associated with the CBL period is higher than the nocturnal period. The turbulence parameters $C_{n}^{2}$ and $\varepsilon$ (gray and black line in 3rd column panel of Fig. 5b) show significant gradient around the top of the boundary layer. It is already mentioned that this sharp gradient feature is utilized to estimate the boundary layer depth. The white circles in all the panels of Fig. 5a correspond to the boundary layer top determined using the radiosonde data. The $C_{n}^{2}$ and $\varepsilon$ values are relatively large during the CBL period and are sparse and sporadic after sunset. The CBL depth, indicated by the enhanced $C_{n}^{2}\left(\sim 10^{-13.5} \mathrm{~m}^{-2 / 3}\right)$, reached as high as $\sim 3.5 \mathrm{~km}$ in between afternoon and sunset while strong $\varepsilon$ values $\left(10^{-3}\right.$ to $10^{-2} \mathrm{~m}^{2} \mathrm{~s}^{-3}$ ) are confined to within the CBL.

Figure 6a (left and right panels) illustrates the mean monthly diurnal variability of the monsoon LLJ during JuneAugust over Gadanki, for the years 1999 and 2000, respectively. The hourly wind profiles of each day of the whole month have been averaged for their respective hours and are presented as a contour map for June (bottom), July (middle) and August (top). The stronger and significant LLJ features are noticed during July 1999, July-August 2000. This type of feature is not observed clearly during June-August 1998 (not shown in figure), which may be due to frequent data gaps and the long break monsoon periods during 1998. The monthly mean diurnal representation shows that the LLJ features are well organized in structure in the late night to just a few hours after sunrise (20:00-08:00 LT), whereas during the daytime (08:00-18:00 LT), either weakened or eroded LLJ features can be seen. Figure $6 \mathrm{~b}$ has four panels (a-d) which bring out the mean diurnal features of the boundary layer, wind ( $V_{h}$ with wind direction and w) and turbulence $\left(C_{n}^{2}\right.$ and $\left.\varepsilon\right)$, parameters. The turbulence parameters are illustrated around the CBL times, i.e. 05:00-18:00 LT only, as the method used is well suitable for CBL periods. During the monsoon season, an elevated inversion layer capping the CBL can be seen very clearly from the HTI plot of $C_{n}^{2}$ in Fig. $6 \mathrm{~b}$ (a). The growth of the CBL is very rapid, reaching a height of $\sim 3 \mathrm{~km}$ during 14:00-16:00 LT. The large values of $\varepsilon$ are confined to a height of $\sim 2 \mathrm{~km}$ and are seen almost all the time. Figure $6 \mathrm{~b}(\mathrm{c})$ shows the diurnal evolution of the horizontal wind speed during the monsoon season and it shows strong westerly winds with a mean wind speed of $\sim 15 \mathrm{~m} \mathrm{~s}^{-1}$, associated with monsoon driven LLJ. The LLJ is strong before 10:00 LT. The bottom panel shows the diurnal evolution of vertical velocity. This plot readily reveals the updrafts throughout the day in the boundary layer, whereas the rest of the seasons show downdrafts during this period (Kalapureddy et al., 2007). During the monsoon season, these low-level updrafts aid in pumping more moisture into the free atmosphere and help in the formation of convective clouds. In general, the monsoon season observations show the mean LLJ core height varying around $1.8 \pm 0.6 \mathrm{~km}$ with average core speeds around $15 \mathrm{~m} \mathrm{~s}^{-1}$. The jet streams are 

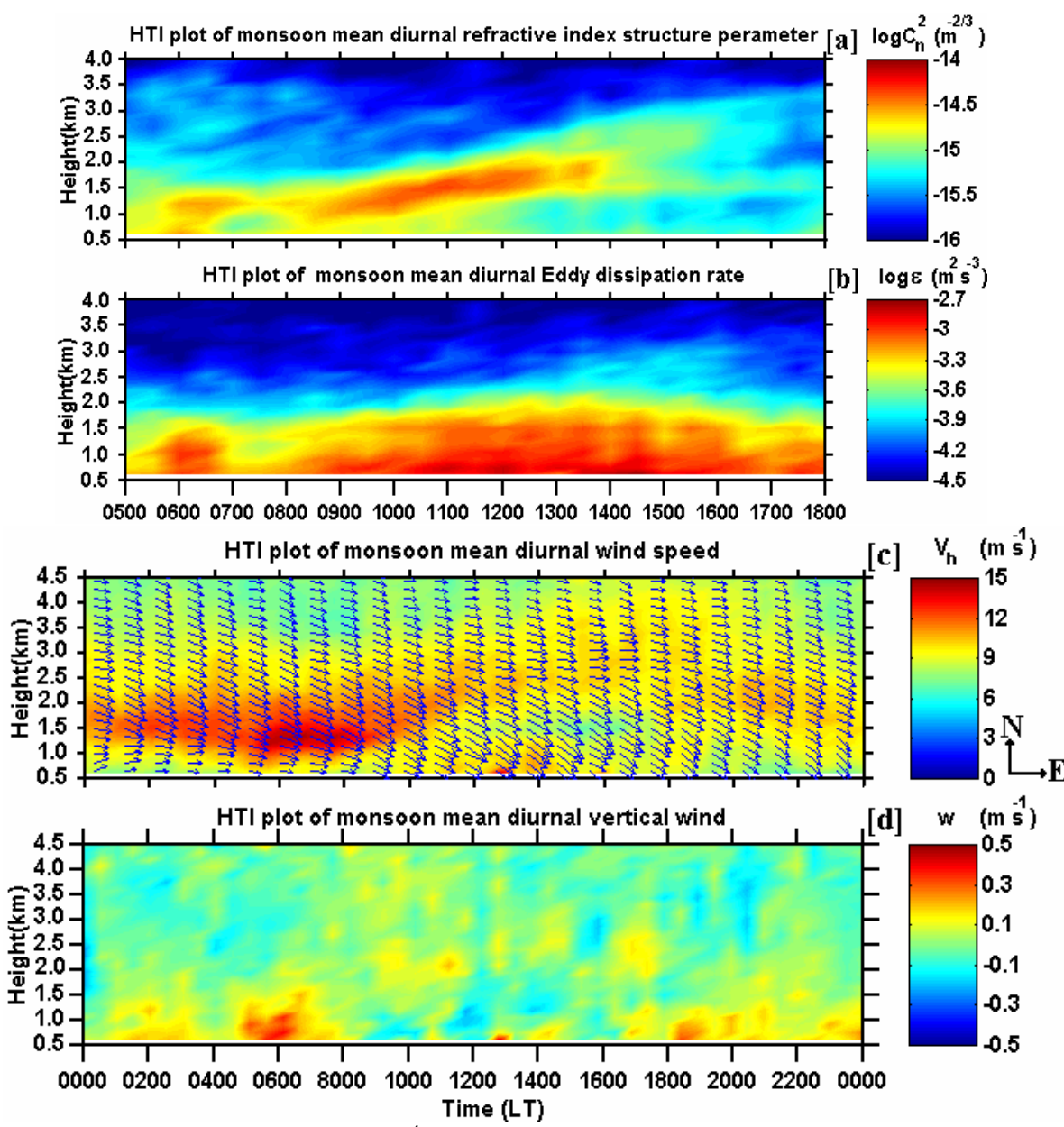

Fig. 6b. Monsoon seasonal diurnal features of (a) $C_{n}^{2}$, (b) $\varepsilon$, (c) $V_{h}$, and (d) W.

steady westerlies in direction. It has also been observed that low-level winds are very steady in direction and variable in speeds, both with height and time.

Figures 4, 5, and 6 clearly show a mutual influence between the LLJ and boundary layer. It can be understood from the figures that the LLJ features have been diluted and sometimes even eroded completely during noontime. Further, high LLJ intensities of the order of greater than $20 \mathrm{~m} \mathrm{~s}^{-1}$ can persist throughout the day without much dilution by the prevailing convective mixing associated with $\mathrm{CBL}$. The strong convective activity associated with CBL during the monsoon season might have been forcing the LLJ core to higher levels and diluting the immediate lower flange of the LLJ, causing reduced LLJ thickness. This apparent shifting or dilution of the jet feature depends on the relative strength of the LLJ and the convective activity associated with the boundary layer. If the LLJ strength is strong enough, the convective activity of CBL can only shift the LLJ structure to higher heights by modifying from beneath. Otherwise, strong mixing associated with the CBL is able to dilute the jet feature, causing homogeneous winds in the CBL. Thus, the mutual strengths of CBL forces and jet strengths can determine the persistence of the LLJ during the daytime.

A good correlation has been found between the LLJ core height and the boundary layer depth determined using maximum shear height (denoted as MSH), $\varepsilon$ (denoted as BLD1) (e.g. Angevine et al., 1994) and $C_{n}^{2}$ (denoted as BLD2) (e.g. Sandra Jacoby-Koaly et al., 2002), with correlation coefficients of $0.97,0.92$, and 0.88 , respectively, seen as a scatter plot in Fig. 7. It indicates that the LLJ core is lying around the boundary layer top.

\section{Conclusions}

Three-year high-resolution LAWP wind observations over Gadanki reveal that the boreal monsoon winds are westerly and conspicuously strong. The strongest LLJ is observed to be associated with the active phase of the monsoon, whereas weak winds with wind reversal are noticed during the break monsoon phase. In brief, the observed monsoon LLJ features are: 

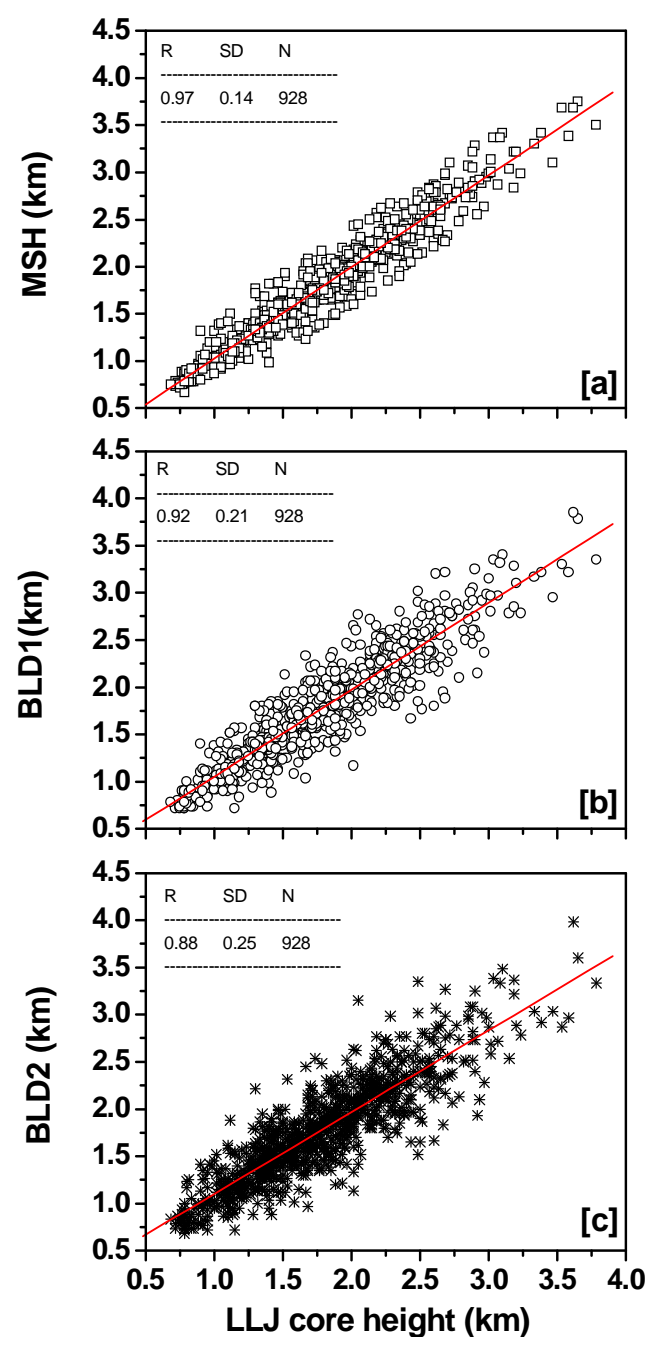

Fig. 7. Scatter plots between LLJ core height and boundary layer top determined using (a) Maximum Shear Height method (denoted as MSH), (b) $\varepsilon$ method (denoted as BLT1), and (c) $C_{n}^{2}$ method (denoted as BLT2). Statistical information can be read as R: correlation coefficient; N: number of data points; SD: standard deviation of the fit.

$\begin{array}{ll}\text { Level of jet core } & 1.8 \pm 0.6 \mathrm{~km} \\ \text { Direction } & \text { Westerly } \\ \text { Mean wind speeds } & \sim 20 \mathrm{~m} \mathrm{~s}^{-1} \\ \text { Max. Wind speed } & 37 \mathrm{~m} \mathrm{~s}^{-1} \\ \text { Diurnal features } & \begin{array}{l}\text { Maximum during early morning } \\ \text { times and diluting during the day- } \\ \text { time }\end{array} \\ \text { Persistence } & \begin{array}{l}\text { Very steady in direction and vari- } \\ \text { able in speeds }\end{array}\end{array}$

The jet structure is more coherently organized during late nighttime to early morning. During active monsoon phases, the LLJ feature has persisted continuously for a few days similar to the Somali Jet (Ardanuy, 1979). The LLJ vertical thickness (spread) is observed to be more than $3 \mathrm{~km}$ during such occasions. CBL forces are responsible for the shifting of the LLJ core by modifying the lower flange of the LLJ. Strong CBL mixing, an exception to a strong LLJ associated with the active monsoon phase, can completely dilute the jet structure and can yield a more homogeneous wind. Strong wind shears that are frequently observed beneath the LLJ indicate that the winds increase very sharply below the core of the LLJ and reduce slowly above the jet core. One notices that the observed LLJ diurnal structures depend on the local convective activity, wind shears and turbulence activity associated with boundary layer winds. The eddy dissipation rate is relatively stronger during the active monsoon phase. The combined high shears and strong convective activity associated with the active phases of the monsoon LLJ are likely to be the main source for such large eddy dissipation rates. It is observed that the LLJ core sits just around the top of the boundary layer. The day-to-day change in the LLJ structure depends on the latitudinal position of the LLJ core. To the best of our knowledge, these high-resolution observations are the first of their kind on the monsoon LLJ. Along with these high-resolution winds, high-resolution meteorological parameters at more locations can provide a chance to look at the horizontal structural characteristics and diurnal features of the LLJ in depth.

Acknowledgements. We are grateful to P. V. Joseph for his encouragement, suggestions and enlightening discussions on this study. Special thanks are due to S. Kumar for helping in NCEP data plots. Department of Space (DOS), Government of India, operates the National Atmospheric Research Laboratory (NARL), formerly NMRF. The LAWP system is established at NMRF under a joint research project between MOPT/CRL, Japan, and DOS/NMRF, India. Authors are thankful to NMRF colleagues, for their every support. We are thankful to the India Meteorological Department (IMD) support for radiosonde campaign at NMRF. One of the authors, M. C. R. Kalapureddy, is thankful to the DOS/ISRO for providing Research Fellowship during the period of the work. He is also grateful to Director, IITM for encouragement of this publication. We are thankful to the anonymous reviewers for their learned comments.

Topical Editor F. D'Andrea thanks three anonymous referees for their help in evaluating this paper.

\section{References}

Anandan, V. K., Balamuralidhar, P., Rao, P. B., Jain, A. R., and Pan, C. J.: An Adaptive Moments Estimation Technique Applied to MST Radar Echoes, J. Atmos. Oceanic Technol., 22, 396-408, 2005.

Angevine, W. M., White, A. B., and Avery, S. K.: Boundary-layer depth and entrainment zone characterization with a boundarylayer profiler, Bound.-Lay. Meteorol., 68, 375-385, 1994.

Ardanuy, P.: On the observed diurnal oscillation of the Somali jet, Mon. Weather Rev., 107, 1694-1700, 1979.

Atlas, D., Srevastava, R. C., and Sloss, P. W.: Wind shear and reflectivity gradient effects on Doppler radar spectra, II. J. Appl. Meterol., 8, 384-388, 1968. 
Desai, B. N., Rangachari, N., and Subramanian, S. K.: Structure of low-level jet stream over the Arabian Sea and the Peninsula as revealed by observations in June and July during the monsoon experiment (MONEX) 1973 and its probable origin, Indian J. Meteorol. Hydrol. Geophys., 27, 263-274, 1976.

Findlater, J.: Cross-equatorial jet streams at low level over Kenya, Meteorological Magazine, 95, 353-364, 1966.

Findlater, J.: Some further evidence of cross-equatorial jet streams at low level over Kenya, Meteorological Magazine, 96, 216-219, 1967.

Findlater, J.: A major low level current near the Indian Ocean during northern summer, Q. J. Roy. Meteor. Soc., 95, 362-380, 1969.

Findlater, J.: Mean monthly air flow at low levels over the western Indian Ocean, Geophysical Memoirs, HMSO, London, 1971.

Findlater, J.: Observational aspects of the Low-level Crossequatorial Jet Stream of the Western Indian Ocean, reprinted from Pageoph., 115, 1251-1262, 1977.

Hart, J. E., Rao, G. V., Van de Boogaard, H., Young, J. A., and Findlater, J.: Aerial observations of the East African low level jet stream, Mon. Weather Rev., 106, 1714-1724, 1978.

Joseph, P. V. and Raman, P. L.: Existence of low-level westerly jetstream over peninsular India during July, Ind. J. Met. Geophys., 17, 437-471, 1966.

Joseph, P. V., Eischeid, J. K., and Pyle, R. J.: Interannual variability of the onset of the Indian summer monsoon and its association with atmospheric features, El Nino, and sea surface temperature anomalies, J. Climate, 7, 81-105, 1994.

Joseph, P. V. and Sijikumar, S.: Intraseasonal Variability of the Low-Level Jet Stream of the Asian Summer Monsoon, J. Climate, 17, 1449-1458, 2004.

Kalapureddy, M. C. R., Kishore Kumar, K., Siva Kumar, V., Ghosh, A. K., Jain, A. R., and Krishna Reddy, K.: Diurnal and seasonal variability of TKE dissipation rate in the ABL over a tropical station using UHF wind profiler, J. Atmos. Sol. Terr. Phys., 69, 419-430, 2007.

Kalnay, E., Kanamitsu, M., Kistler, R., et al.: The NCEP/NCAR 40-year reanalysis project, B. Am. Meteorol. Soc., 77, 437-471, 1996.

Krishnan, P. and Kunhikrishnan, P. K.: Temporal variations of ventilation coefficient at a tropical Indian station suing UHF wind profiler, Curr. Sci., 86, 447-451, 2004.

Krishnan, P., Kunhikrishnan, P. K., and Nair, S. M.: Timeheight evolution of intraseasonal oscillations in the tropical lower atmosphere, Geophys. Res. Lett., 32, L07805, doi:10.1029/2004GL022019, 2005.

Krishnamurti, T. N., Molinari, J., and Pan, H. L.: Numerical simulation of the Somali Jet, J. Atmos. Sci., 33, 2350-2362, 1976.

Krishnamurti, T. N., Wong, V., Pan, H. L., Pasch, R., Molinari, J., and Ardanuy, P.: A three dimensional planetary boundary layer model for Somalijet, J. Atmos. Sci., 40, 894-908, 1983.

Krishnamurti, T. N.: Summer monsoon experiment-A review, Mon. Weather Rev., 113, 1590-1626, 1985.

Krishna Reddy, K., Kozu, T., Ohno, Y., Nakamura, K., Srinivasula, P., Anandan, V. K., Jain, A. R., Rao, P. B., Ranga Rao, R., Viswanthan, G., and Rao, D. N.: lower atmospheric wind profiler at Gadanki, Tropical India: initial result, Meterologische Zeitschrift, 10, 457-466, 2001

Krishna Reddy, K., Kozu, T., Ohno, Y., Nakamura, K., Higuchi, A., Madhu Chandra Reddy, K., Anandan, V. K., Srinivasulu, P., Jain,
A. R., Rao, P. B., Ranga Rao, R., Viswanathan, G., and Narayana Rao, D.: Planetary boundary layer and precipitation studies using lower atmospheric wind profiler over tropical India, Radio Sci., 37(4), 1061, doi:10.1029/2000RS002538, 2002.

Krishna Reddy, K.: Convective boundary layer information revealed by the lower atmospheric wind profiler over Gadanki, India, Indian J. Radio Space Phys., 32, 312-319, 2003 a.

Krishna Reddy, K.: Measurements of raindrop size distribution over Gadanki during southwest and northeast monsoon, Indian J. Radio Space Phys., 32, 286-295, 2003b.

Krishna Reddy, K.: Diagnostic study on vertical structure of tropical precipitating cloud systems using lower atmospheric wind profiler, Indian J. Radio Space Phys., 32, 198-208, 2003c.

Krishna Reddy, K. and Ohno, Y.: Monitoring of boundary layer winds using a lower atmospheric wind profiler, Indian J. Radio Space Phys., 32, 360-372, 2003d.

Madhu C. Reddy, K., Ghosh, A. K., Siva Kumar, V., Jain, A. R., Kozu, T., and Krishna Reddy, K.: Integrated measurements of atmospheric winds using Indian MST radar and Lower Atmospheric Wind Profiler (LAWP), in: Proceedings of 9th International Workshop on Technical and Scientific Aspects of MST Radar-MST combined with COST-76 final profiler workshop during 13-17 March 2000, Toulouse, France, 222-225, 2000.

Mokashi, R. Y.: The axis of the tropical easterly jet stream over India and Cyclone, Indian J. Meteorol. Geophys., 25(1), 55-68, 1974.

Newton, C. W.: Lagrangian partial-inertial oscillations, and subtropical and low level monsoon jet streatks, Mon. Weather Rev.,109, 2474-2486, 1981.

Riddle, A. C.: Parameterization of spectrum, in: MAP handbook, SCOSTEP Secr., edited by: Bowhil, S. A. and Edwards, B., Urbana,III., 9, 546-547, 1983.

Sandra Jacoby-Koaly, S., Campistron, B., Bernard, S., Blnech, B. Ardiiuin-Girard, F., Dessens, J., Dupont, E., and Carissimo, B.: Turbulent dissipation rate in the boundary-layer via uhf wind profiler doppler spectral width measurements, Boundar-Lay. Meteorol., 103, 361-389, 2002.

Stensrud, D. J., Jain, M. H., Howard, K. W., and Maddox, R. A.: Operational systems for observing the lower atmosphere: Importance of data sampling and archival procedures, J. Atmos. Oceanic Technol., 7, 930-937, 1990.

Stensrud, D. J.: Importance of low level jets to climate: A review, J. Climate, 9, 1698-1711, 1996.

Stull, R. B.: An introduction to Boundary Layer Meteorology, Kluwer Academic publication, Boston, 500-522, 1990.

White, A. B.: Mixing depth detection using 915-MHz radar reflectivity data, Proceedings of the 8th symposium on meteorological observations and instrumentation, Anaheim, CA, American Meteorological Society, 45 Beacon St., Boston, MA, 248-250, 1993.

Wipperman, F.: Numerical study on the effects controlling the low level jet, Beitr. Phys. Atmos., 46, 137-154, 1973.

Woodman, R. F.: Spectral moment estimation in MST radars, Radio Sci., 20(6), 1185-1195, 1985

Yihua Wu and Sethu Raman: The summertime Great Plains low level jet and the effects of its origin on moisture transport, Boundary-Lay. Meteorol., 88, 445-466, 1998. 